\title{
Acid mine drainage and stream recovery: Effects of restoration on water quality, macroinvertebrates, and fish
}

\author{
K.M. Williams ${ }^{(1)}$, A.M. Turner ${ }^{(1), \star}$ \\ Received February 6, 2015 \\ Revised May 19, 2015 \\ Accepted June 2, 2015
}

\section{ABSTRACT}

Key-words: acid-mine drainage, stream acidification, watershed remediation, water quality, biological recovery

\begin{abstract}
Acid mine drainage (AMD) is a prominent threat to water quality in many of the world's mining districts as it can severely degrade both the biological community and physical habitat of receiving streams. There are relatively few long-term studies investigating the ability of stream ecosystems to recover from AMD. Here we assess watershed scale recovery of a coldwater stream from pollution by AMD using a 1967 survey of the biological and chemical properties of the stream as a pre-restoration benchmark. We sampled water chemistry, benthic macroinvertebrates, and fish throughout the watershed during the spring and summer of 2011. Water chemistry results indicated that $\mathrm{pH}$ and total alkalinity increased post-restoration, while acidity, sulfate, and iron concentrations decreased. Watershedlevel taxa richness, local taxa richness, biomass, diversity, and density of macroinvertebrates were significantly higher post-restoration; however, $\%$ EPT was not significantly different. Fish species richness, density, and brook trout density were all significantly higher post-restoration. These results provide clear evidence that both abiotic and biotic components of streams can recover from AMD pollution.
\end{abstract}

Drainage minier acide et restauration d'une rivière : effets de la restauration sur la qualité de l'eau, des macroinvertébrés et des poissons

Mots-clés:
drainage
acide minier,
acidification,
assainissement
de bassin
versant,
qualité de l'eau,
reconquête
biologique

Le drainage minier acide (AMD) est une menace importante à la qualité de l'eau dans de nombreux districts miniers du monde, car il peut endommager gravement à la fois la communauté biologique et l'habitat physique des cours d'eau récepteurs. II y a relativement peu d'études à long terme sur la capacité des écosystèmes des cours d'eau à récupérer de l'AMD. Ici, nous évaluons la récupération à l'échelle d'un bassin versant d'un cours d'eau froid après pollution par AMD en utilisant un suivi fait en 1967 des propriétés biologiques et chimiques de la rivière comme référence pré-restauration. Nous avons échantillonné la chimie de l'eau, les macroinvertébrés benthiques, les poissons, dans tout le bassin au cours du printemps et de l'été 2011. Les résultats de la chimie de l'eau ont révélé que le $\mathrm{pH}$ et l'alcalinité totale ont augmenté post-restauration, alors que l'acidité, les concentrations en sulfate et en fer ont diminué. La richesse en taxons à l'échelle du bassin versant, la richesse locale en taxons, la biomasse, la diversité et la densité des macroinvertébrés étaient significativement plus élevées après restauration; 
cependant le \% EPT n'était pas significativement différent. La richesse et la densité spécifique des poissons, la densité d'ombles de fontaine sont toutes sensiblement plus élevées post-restauration. Ces résultats démontrent clairement que les deux éléments abiotiques et biotiques des cours d'eau peuvent se remettre de la pollution AMD.

\section{INTRODUCTION}

Acid mine drainage (AMD) is a persistent cause of water quality impairment in regions of the world that have experienced mining for coal or metal ores (Simate and Ndlovu, 2014). In the Northern Appalachians sub-region of the United States, approximately $10 \%$ of stream reaches are acidified by drainage from abandoned coal mines (Herlihy et al., 1990). The formation of $A M D$ is triggered by a change in hydrology typically associated with mining. The large-scale earth disturbances expose pyrite $\left(\mathrm{FeS}_{2}\right)$ and similar sulfide-bearing minerals to water and oxygen, which through a series of chemical reactions produces discharges with low $\mathrm{pH}$ and elevated concentrations of sulfates, iron, aluminum, and other dissolved metals (Johnson, 2003; Akcil and Koldas, 2006; Jacobs et al., 2014). Mine drainage enters surface waters through abandoned wells, mine openings, springs, or seeps in the watershed and can cause large reductions in stream $\mathrm{pH}$ and increases in dissolved metals. AMD can also degrade the physical habitat of streams, as iron hydroxide and other precipitates can clog interstitial spaces and cement substrate particles (DeNicola and Stapleton, 2002). These conditions can lead to declines in benthic macroinvertebrate richness, abundance, diversity, and biomass (Gerhardt et al., 2004; Van Damme et al., 2008; Alvial et al., 2012), as well as depressed fish abundance and diversity (Henry et al., 1999).

Economic costs associated with AMD-degraded waterways include increased costs for drinking water treatment, a decline in property values, and the loss of recreational opportunities. A substantial sum of government and private funds has been invested in an effort to mitigate AMD pollution. For example, the United States federal government has distributed more than 7.6 billion USD since 1977 via the Abandoned Mine Land Trust Fund, which is just one of several federal programs that fund remediation of water quality issues stemming from coal mining (United States Department of the Interior, 2015). Remediation techniques include filling, re-contouring, and re-vegetating surface mines, removing spoil piles, backfilling deep mines and boreholes, plugging abandoned oil and gas wells, as well as a variety of active (periodic chemical inputs) and passive treatment systems designed to treat polluted discharges before they enter streams (review in Johnson and Hallberg, 2005).

In-stream water quality monitoring has been used to assess the effectiveness of AMD remediation efforts, but has typically been limited to evaluating stream reaches adjacent to the remediation site and sustained over short time spans (Wohl et al., 2005). Biological recovery may be slow because AMD involves physical degradation of the benthic habitat, and because recolonization by fish and insects can require long time spans. Additionally, the underlying problems usually encompass entire watersheds. Ultimately, long-term, watershed-scale monitoring efforts are necessary to assess the success of AMD remediation.

Despite the large body of research on AMD remediation, there are only a few studies that encompass large reaches and span decades. Considering the large expenditures directed towards AMD remediation, there is a clear need additional for pre- and post-restoration data collected over large spatial and temporal scales. Tom's Run, a stream that was historically polluted by acid mine drainage but has since been the site of various remediation efforts, provides an opportunity to assess watershed level recovery using data collected both before and after several decades of restoration. 


\section{FIELD-SITE DESCRIPTION}

Tom's Run (lower limit latitude: 41.331902, lower limit longitude: -79.207748 ) is a poorly buffered, cold-water stream that drains a $32.4 \mathrm{~km}^{2}$ watershed in northwestern Pennsylvania, USA. Ninety-four percent of the watershed is forested, primarily by northern hardwood species and Tsuga canadensis (Eastern Hemlock). Most of the watershed is contained within the boundaries of Cook Forest State Park, and thus development of infrastructure is minimal and human population density is low. Other than the mining activity described below, there have been no significant changes in land use in recent decades.

Historically, there was extensive surface mining of coal from the ridges that form the periphery of the watershed (Merritt and Emrich, 1970), though mining ceased by the 1960's. Rain water percolating through the abandoned surface mines dissolved pyrite and resulted in widespread groundwater pollution (Merritt and Emrich, 1970; Stafford et al., 2004). Groundwater, confined between layers of shale and following plunging strata, carried the dissolved pyrite several kilometers or more from the mines and towards Tom's Run, sometimes from outside the boundaries of the surficial drainage basin. The polluted groundwater eventually emerged as artesian springs and seeps through a wide portion of the watershed (Stafford et al., 2004). In response to concern regarding the deteriorating water quality in Tom's Run, Dinsmore (1968) surveyed water chemistry, benthic macroinvertebrates, fish, and algae at locations along the entire mainstem of Tom's Run as well as in all of the tributaries. Based in part on Dinsmore's assessment, reclamation efforts were implemented between 1970 and 2000. Surface mines in the headwaters were recontoured and revegetated, deep mines were sealed and injected with a lime slurry, nearly all of the abandoned gas and oil wells in the watershed were plugged, and a passive treatment system including an anoxic limestone drain and two settling ponds was installed to treat a remaining AMD discharge (Merritt and Emrich, 1970; Hedin, 2001).

Because Dinsmore's study was completed before remediation efforts were implemented, the watershed provides a valuable opportunity to evaluate the long-term recovery of a watershed subject to AMD pollution. We gathered post-restoration data during spring and summer 2011, surveying the same sites and utilizing the same sampling methodology as Dinsmore (1968), and demonstrate how pre- and post-restoration data collected over a 44-year time span can be used to quantitatively assess the watershed level recovery of Tom's Run from AMD.

\section{METHODS}

\section{> SAMPLING LOCATIONS AND DESCRIPTIONS}

Using Dinsmore's (1968) descriptions, we revisited 12 sample sites along the mainstem of Tom's Run, located at approximately equidistant intervals from the headwaters to the mouth. Sampling dates were chosen to coincide with Dinsmore's collection dates, and his sampling methodology was replicated as accurately as possible. Water chemistry and macroinvertebrate data were collected in both spring and summer of 2011. Spring collections occurred in late May, and summer collections occurred in mid-July. Fish were sampled once in late July. All sampling was conducted under stable, base flow conditions.

\section{> WATER CHEMISTRY}

$\mathrm{pH}$, temperature, and dissolved oxygen were measured in the field using a YSI-556 MultiProbe-System calibrated to manufacturer's specifications. Water samples were collected in acid-washed $500 \mathrm{~mL}$ polyethylene bottles at each sampling site and transported on ice to an analytical laboratory for immediate analysis. Laboratory analyses of unfiltered water were conducted using Inductively Coupled Plasma Atomic Emission Spectroscopy for determination of total iron and sulfates. Total alkalinity and free acidity titrations were conducted following standard protocols (APHA, 1998). Samples were titrated to $\mathrm{pH} 8.3$ with $0.02 \mathrm{~N}$ sodium 
hydroxide to determine free acidity, and $\mathrm{pH} 4.5$ with $0.02 \mathrm{~N}$ sulfuric acid to determine total alkalinity. Because we were interested in overall effects of restoration on water quality, we averaged spring and summer values for further analysis. $\mathrm{pH}$ values are the logarithm of hydrogen ion concentrations, so average $\mathrm{pH}$ values represent geometric mean of hydrogen ion concentration.

\section{> MACROINVERTEBRATES}

Benthic macroinvertebrates were sampled using a $0.09 \mathrm{~m}^{2}$ Surber sampler. At each site, three samples were collected in separate riffles in accordance with Dinsmore's methodology. Macroinvertebrates were picked in the field and blotted to remove excess water before being transferred to an aluminum pan and weighed on a portable balance to determine live biomass. After weighing, specimens were preserved in $70 \%$ ethanol and later identified to genus and counted. Crayfish were collected but not included in the macroinvertebrate biomass; they were counted and returned to the stream. We calculated local taxonomic richness (mean number of genera per site), regional taxonomic richness (total number of genera across all sites), macroinvertebrate density (mean number of individuals per $\mathrm{m}^{2}$ ), \% EPT (mean percent of total individuals comprised of Ephemeroptera, Plecoptera, and Trichoptera at each site), mean Shannon Wiener Diversity Index, and live biomass (mean $\mathrm{mg} \cdot \mathrm{m}^{-2}$ ). Watershed means were calculated by first averaging spring and summer values, and then averaging across sample sites. Jaccard's Similarity Index, which describes the proportion of shared taxa, was used to evaluate the similarity of the macroinvertebrate assemblage between 1967 and 2011.

\section{$>$ FISH}

Fish were sampled using a pulsed-DC backpack electrofishing unit over a $100 \mathrm{~m}$ transect at each sampling site, and each fish was identified to species before being returned to the stream. We calculated local species richness (mean number of fish species per $100 \mathrm{~m}$ transect), regional species richness (total number of fish species across all sites), fish density (mean number per $100 \mathrm{~m}$ transect), and brook trout density (mean number per $100 \mathrm{~m}$ transect).

\section{> STATISTICAL ANALYSIS}

Paired $t$-tests were used to test for significant changes in water chemistry parameters, macroinvertebrate assemblage metrics, and fish metrics, between 1967 and 2011. A paired t-test, used in this way, is equivalent to an ANOVA with sample sites as blocks, and tests whether the mean value of each variable, averaged across sample sites, changed significantly between 1967 and 2011. Macroinvertebrate biomass data did not follow a normal distribution and were therefore log-transformed. Fish density and brook trout density were also non-normally distributed, and included zero values, therefore a $\log (x+1)$ transformation was applied. Dinsmore had missing data for several variables, so respective data from 2011 sampling sites were excluded from analysis in order to make paired comparisons.

\section{RESULTS}

\section{> WATER CHEMISTRY}

Since 1967, pH in Tom's Run has increased by approximately 1.3 points (Figure 1A) which corresponds with a 20 -fold decline in acidity. Mean free acidity has also declined, 

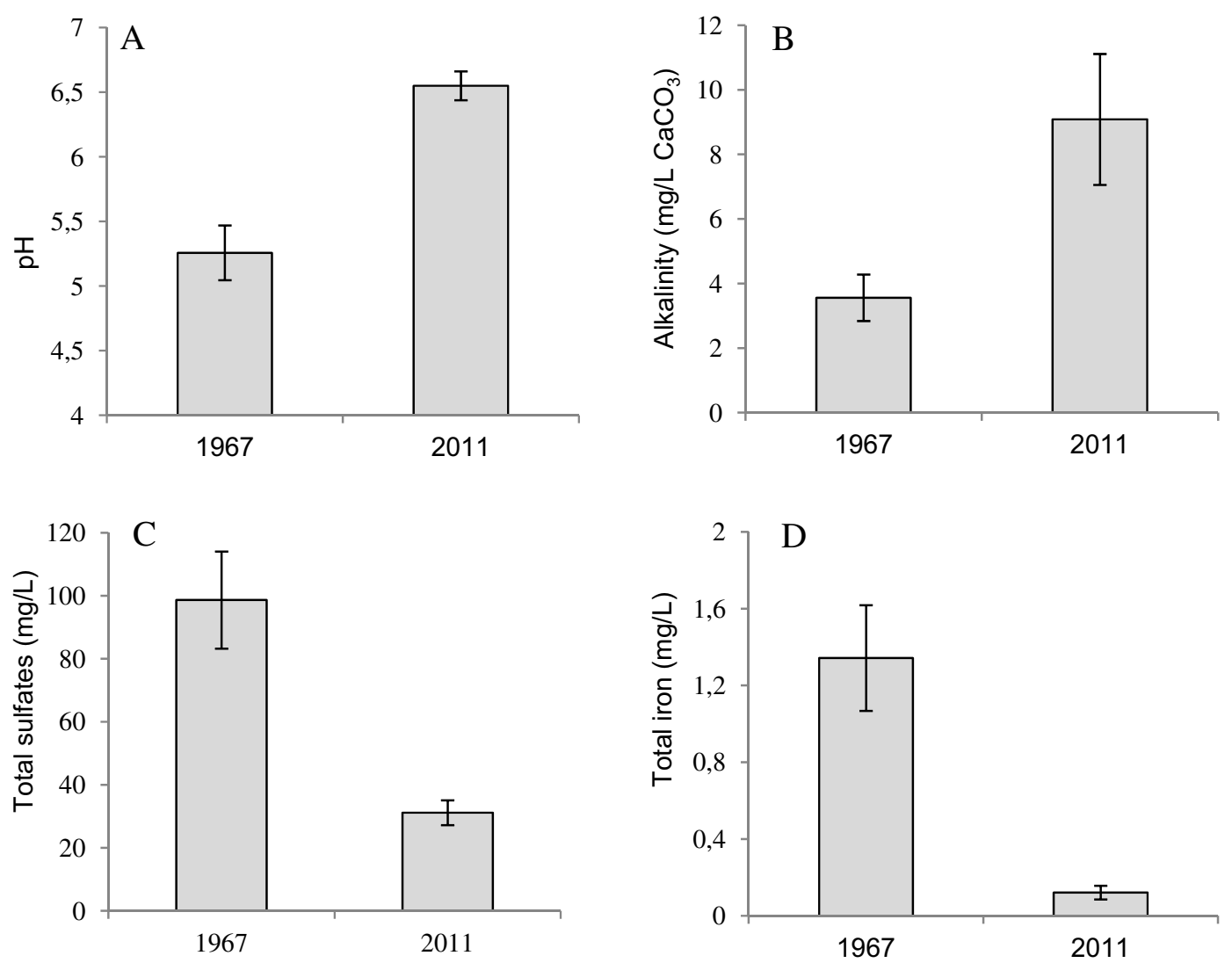

\section{Figure 1}

Water chemistry parameters averaged across all sites on Tom's Run in 1967 and 2011. Error bars represent one standard error of the mean; $N=11$ sites for $p H$, sulfates, and iron, and $N=7$ sites for alkalinity.

from $23.24 \mathrm{mg} \cdot \mathrm{L}^{-1} \mathrm{CaCO}_{3}$ in 1967 to $3.48 \mathrm{mg} \cdot \mathrm{L}^{-1}$ in 2011 . Alkalinity has more than doubled (Figure 1B) but is still generally low. Sulfate and iron concentrations have decreased, with a $68 \%$ reduction in sulfates (Figure $1 \mathrm{C}$ ), and a 90\% reduction in iron (Figure 1D). All of these changes in water chemistry parameters are statistically significant (Table I). Tom's Run is relatively cold (mean temperature $=15.1^{\circ} \mathrm{C}$ ) and oxygen saturated (mean dissolved oxygen $=$ $\left.9.25 \mathrm{mg} \cdot \mathrm{L}^{-1}\right)$. Temperature and dissolved oxygen have remained very similar to values measured in 1967 (<5\% difference) and mean values were not significantly different (Table I).

\section{> MACROINVERTEBRATES}

Macroinvertebrate density was substantially higher in 2011 than in 1967, with the mean density increasing from 7 individuals. $\mathrm{m}^{-2}$ in 1967 to 27 individuals. $\mathrm{m}^{-2}$ in 2011 (Figure 2A). Macroinvertebrate biomass also increased dramatically, from $43 \mathrm{mg} \cdot \mathrm{m}^{-2}$ in 1967 to $301 \mathrm{mg} \cdot \mathrm{m}^{-2}$ in 2011 , or approximately a 6 -fold increase (Figure 2B). These increases were both statistically significant (Table I).

Regional richness, represented by the total number of macroinvertebrate genera found throughout the entire watershed, more than doubled from 25 in 1967 to 63 in 2011. Similarly, local taxonomic richness (mean number of macroinvertebrate genera per sampling site) was much higher in 2011 than in 1967, with a mean increase of 12 genera (Figure 2C). Also, the macroinvertebrate assemblage of 2011 was much more diverse than in 1967, with a Shannon Wiener Diversity Index of 2.04 in 2011 versus 0.90 in 1967. These increases in richness and diversity were all statistically significant (Table I).

The representation of EPT taxa increased from $57.6 \%$ in 1967 to $79.3 \%$ in 2011 , but this increase was not statistically significant (Table I). Jaccard's Similarity index indicated that 


\section{Table I}

Results of paired sample t-tests comparing watershed means for water chemistry parameters and metrics of macroinvertebrate and fish community structure of Tom's Run between 1967 and 2011.

\begin{tabular}{|c|c|c|c|}
\hline Variable & $t$-Statistic & df & $\overline{p \text {-value }}$ \\
\hline $\mathrm{pH}$ & 5.421 & 10 & $<0.001$ \\
\hline Total iron $\left(\mathrm{mg} \cdot \mathrm{L}^{-1}\right)$ & 3.559 & 10 & 0.005 \\
\hline Total sulfates $\left(\mathrm{mg} \cdot \mathrm{L}^{-1}\right)$ & 3.417 & 10 & 0.007 \\
\hline Total alkalinity $\left(\mathrm{mg} \cdot \mathrm{L}^{-1} \mathrm{CaCO}_{3}\right)$ & 5.232 & 6 & 0.002 \\
\hline Free acidity $\left(\mathrm{mg} \cdot \mathrm{L}^{-1} \mathrm{CaCO}_{3}\right)$ & 2.936 & 10 & 0.015 \\
\hline Temperature $\left({ }^{\circ} \mathrm{C}\right)$ & 0.971 & 10 & 0.354 \\
\hline Dissolved oxygen $\left(\mathrm{mg} \cdot \mathrm{L}^{-1}\right)$ & 0.790 & 10 & 0.448 \\
\hline $\begin{array}{l}\text { Macroinvertebrate taxonomic richness } \\
\text { (number of genera/site) }\end{array}$ & 14.193 & 10 & $<0.001$ \\
\hline $\begin{array}{l}\text { Macroinvertebrate density } \\
\text { (number of individuals per site) }\end{array}$ & 5.120 & 10 & $<0.001$ \\
\hline $\begin{array}{l}\text { Macroinvertebrate Shannon } \\
\text { Wiener diversity }\end{array}$ & 3.911 & 10 & 0.003 \\
\hline$\%$ EPT & 1.453 & 10 & 0.117 \\
\hline $\begin{array}{l}\text { Macroinvertebrate biomass } \\
\left(\mathrm{mg} \cdot \mathrm{m}^{-2}\right)\end{array}$ & 5.249 & 10 & $<0.001$ \\
\hline $\begin{array}{l}\text { Fish species richness } \\
\text { (mean number of species/site) }\end{array}$ & 12.649 & 4 & $<0.001$ \\
\hline $\begin{array}{l}\text { Fish density } \\
\text { (mean number of individuals } / 100 \mathrm{~m} \text { transect) }\end{array}$ & 9.934 & 4 & 0.001 \\
\hline $\begin{array}{l}\text { Brook trout density } \\
\text { (mean number/100 } \mathrm{m} \text { transect) }\end{array}$ & 3.750 & 4 & 0.020 \\
\hline
\end{tabular}
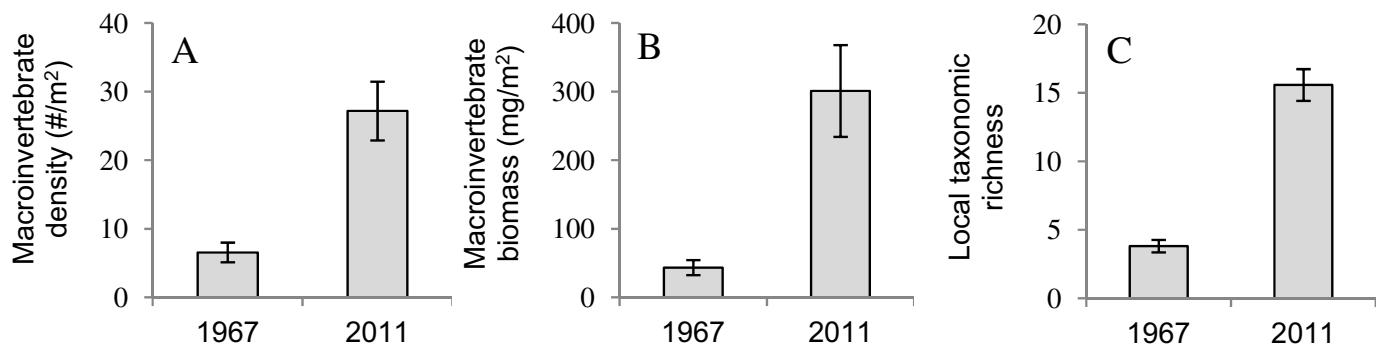

Figure 2

Macroinvertebrate data averaged across sampling sites on Tom's Run in 1967 and 2011. Error bars represent one standard error of the mean; $N=11$ sites. Macroinvertebrate taxonomic richness is the mean local richness (\# taxa / site).

just $26 \%$ of the genera collected were shared in the sample years. The stonefly, Leuctridae Leuctra, was the most common genus collected in both surveys. Other dominant genera collected in both surveys included the caddisfly Hydropsychidae Hydropsyche, the stonefly Nemouridae Amphinemura, and the non-biting midge Chironomidae Chironominae. Overall, the identity of the dominant taxa was surprisingly similar in 1967 and 2011 (Table II), and the major change in macroinvertebrate species composition is attributable to addition of numerous taxa in 2011.

\section{$>$ FISH}

Regional richness of fish more than doubled between sampling years, increasing from 3 species collected throughout the entire watershed in 1967 to 7 in 2011. Similarly, local taxonomic richness was higher in 2011 than in 1967, with a mean increase of 4 species 


\section{Table II}

Ten most abundant macroinvertebrate genera collected from Tom's Run in 1967 and 2011. Data from spring and summer samples have been pooled.

\begin{tabular}{|l|c|c|c|}
\hline 1967-Most dominant taxa & \% of total & 2011-Most dominant taxa & \% of total \\
\hline Leuctridae Leuctra & 33.4 & Leuctridae Leuctra & 30.48 \\
\hline Chironomidae "A" & 30.64 & Hydropsychidae Hydropsyche & 11.43 \\
\hline Nemouridae Amphinemura & 14.68 & Philopotamidae Dolophilodes & 7.77 \\
\hline Hydropsychidae Hydropsyche & 7.02 & Nemouridae Amphinemura & 6.4 \\
\hline Simuliidae Simulium & 3.19 & Chironomidae Chironominae & 4.01 \\
\hline Sialidae Sialis & 1.7 & Simuliidae Prosimulium & 3.81 \\
\hline Rhyacophilidae Rhyacophila & 1.7 & Chloroperlidae Alloperla & 3.03 \\
\hline Chironomidae "B" & 1.06 & Baetidae Baetis & 3.03 \\
\hline Oligochaeta & 1.06 & Tipulidae Dicranota & 2.54 \\
\hline Limnephilidae & 0.85 & Heptageniidae Epeorus & 2.3 \\
\hline
\end{tabular}
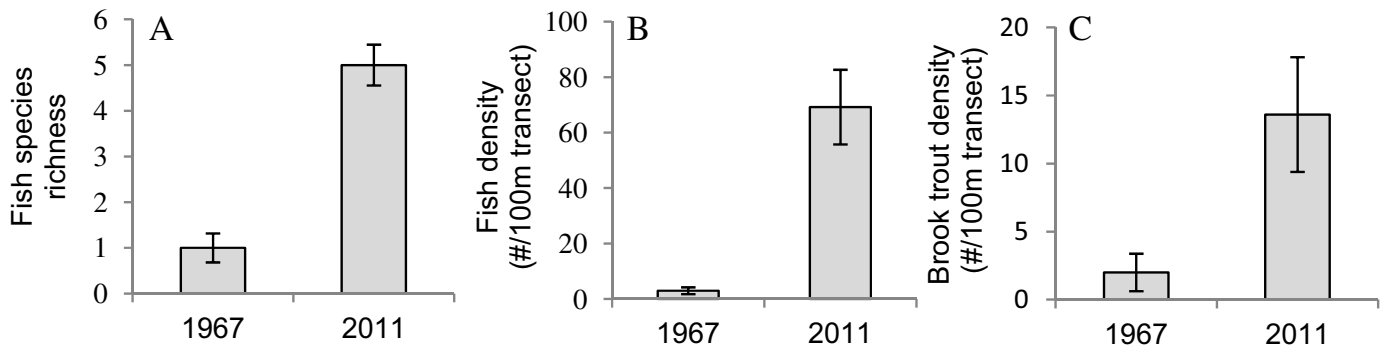

\section{Figure 3}

Fish data averaged across sampling sites on Tom's Run in 1967 and 2011. Error bars represent one standard error of the mean; $N=5$ sites. Fish species richness is the mean local richness (\# species $/ 100 \mathrm{~m}$ transect).

\section{Table III}

Species composition of fish sampled from Tom's Run in 1967 and 2011. Stocked brook trout were excluded from this analysis.

\begin{tabular}{|l|c|c|c|}
\hline 1967 & \% of total & 2011 & $\%$ of total \\
\hline Brook trout & 66.7 & Blacknose dace & 39.1 \\
\hline Creek chub & 20.0 & Mottled sculpin & 32.2 \\
\hline White sucker & 13.3 & Brook trout & 17.8 \\
\hline & & White Sucker & 6.5 \\
\hline & & Creek chub & 3.0 \\
\hline & & Pumpkinseed sunfish & 1.2 \\
\hline & & Largemouth bass & 0.3 \\
\hline
\end{tabular}

per $100 \mathrm{~m}$ transect (Figure 3A). Mean fish density, or the number of individuals collected per 100 m transect, was much higher in 2011 than in 1967, with the mean increasing from 3 to 69 fish (Figure 3B). Lastly, the density of brook trout was also substantially higher in 2011, with the mean increasing from 2 to 14 per $100 \mathrm{~m}$ transect, or a 5.8-fold increase (Figure 3C). Increases in local taxonomic richness, fish density, and brook trout density were all statistically significant (Table I). The dominant fish species collected in 1967 was the brook trout, an acid tolerant species (Table III). The dominant species collected in 2011 were the blacknose dace and mottled sculpin, species that are relatively intolerant to acidity (Table III).

\section{DISCUSSION}

Our study shows that water quality has improved significantly throughout the Tom's Run watershed following the implementation of AMD remediation efforts. Between 1967 and 2011, mean $\mathrm{pH}$ and alkalinity increased, and mean free acidity, sulfate, and iron concentrations declined. Biological recovery can be highly variable and contingent on factors other than water 
chemistry (e.g. Louhi et al., 2011; Sundermann et al., 2011, Johnson et al., 2014), but the results of our study also show large improvements in most aspects of the biological community of our study system. Local macroinvertebrate taxonomic richness, mean macroinvertebrate density, mean live biomass, and Shannon Wiener diversity index were all significantly higher in 2011 (post-restoration) than in 1967 (pre-restoration), and regional taxonomic richness throughout the watershed more than doubled after remediation efforts were implemented. These results are consistent with studies showing that degradation of water quality from AMD is typically associated with a reduction in the diversity and abundance of macroinvertebrates (Tomkiewicz and Dunson, 1977; Kimmel, 1983), and studies demonstrating biological recovery from AMD following restoration (Nelson and Roline, 1996; Gunn et al., 2010).

Although many of the studies of recovery from AMD are of limited temporal and spatial scale, there are several notable exceptions in the recent literature. Studies that encompass entire watersheds include Bott et al., 2012, Kruse et al., 2013, and Johnson et al., 2014. Interestingly, one of the conclusions drawn from all three of these studies is that the spatial scale of recovery depended on the variable under consideration. Water quality improvements were evident a short distance from treatment sites, but community and ecosystem level patterns and processes required larger zones of recovery. There are fewer studies of AMD recovery that encompass a decadal or longer time scale, with the long-term study of Swatara Creek (e.g. Cravotta et al., 2010) being a notable example. Cravotta et al. found that temporal trends also depend on the variable measured, as water quality improved more quickly than did the structure and function of the biological community. Our study encompasses perhaps the longest time frame (44 years) of any of the AMD recovery studies, and the robust biological recovery we document here may be a product of the long time span involved.

The EPT metric is often calculated because mayflies, stoneflies, and caddisflies are assumed to be intolerant of pollution and thus indicators of high quality aquatic environments (Plafkin et al., 1989; Bain et al., 2000). However, we found that the \% EPT increased only modestly between 1967 and 2011 and that the difference was not statistically significant. Contrary to the presumption that the EPT index represents intolerant taxa, two of the dominant taxa in Tom's Run in both 1967 and 2011, Leuctra and Amphinemura, are moderately acid-tolerant (Sutcliffe and Hildrew, 1989; Dangles et al., 2004) and thus their numbers did not decline when the stream was polluted. In Tom's Run, metrics of abundance, biomass, richness, and diversity were sensitive indicies for detecting changes in water quality, but metrics based on species composition were insensitive indicators of improvement. Thus, we suggest that EPT and other indicies of biotic integrity based on the identity of the dominant species be used with caution.

It is interesting to note that although the identity of the dominant macroinvertebrate taxa collected were relatively similar both pre- and post-restoration, overall, only $26 \%$ of the genera were shared. The five most dominant taxa in 1967 remained among the top six in 2011, but many additional taxa were added following restoration. This shows that the dominant taxa in Tom's Run have not been replaced by less-tolerant taxa as water quality improved. Instead, enhanced water quality has allowed numerous additional macroinvertebrate taxa, including intolerant taxa, to colonize the system. Changes in species composition along environmental gradients can follow two different patterns, either the addition of more species (nestedness), or the replacement with new species (turnover) (Matthews, 1998). Thus, considering the trajectory of recovery as an environmental gradient, our macroinvertebrate community appears to show signficant nestedness along the recovery gradient, but not significant turnover (sensu Leibold and Mikkelson, 2002).

Dinsmore found only 3 species of fish when he surveyed Tom's Run in 1967 before the implementation of remediation efforts, which is consistent with studies that show streams affected by AMD tend to have lower overall abundance and diversity of fish (Kimmel and Argent, 2010). After restoration, the fish community rebounded, as evidenced by a doubling in watershed-level richness (7 species), and substantially higher local fish species richness, fish density, and brook trout density. Thus, remediation efforts were successful in allowing for recolonization of several additional taxa and in promoting a large increase in fish abundance. 
As with the macroinvertebrate community, the fish species present in 1967 remained abundant in 2011, showing that enhanced water quality allowed for the addition of more fish species into the system (nested assemblages), as opposed to promoting species turnover.

Without knowledge of stream conditions in Tom's Run prior to pollution by AMD, we cannot quantitatively evaluate resilience, i.e. whether remediation efforts have allowed Tom's Run to return to its pre-disturbance state; however, several lines of evidence suggest that Tom's Run has met widely accepted criteria for recovery. Tom's Run is currently meeting all state and federal criteria for its designated uses (e.g. Clean Water Act standards), and based on the presence of a naturally reproducing population of wild brook trout, has been designated by the Commonwealth of Pennsylvania as a Wild Trout Stream. In addition, our personal observations indicate that the stream is similar to other relatively undisturbed, coldwater streams in the region in terms of water chemistry parameters, macroinvertebrate community structure, and fish abundance and diversity.

It is difficult to evaluate the role of specific reclamation activities in the restoration of Tom's Run because a variety of remediation efforts have been implemented, and because there is some evidence that over time AMD discharges will attenuate without abatement efforts as acid-forming minerals are depleted from exposed overburden. Studies have found significantly lower pollution loads after approximately 40 years in untreated watersheds (Wood et al., 1999), and a reduction in acidity at a rate of about 2\% per year (Mack et al., 2010). Thus, it is possible then that the water quality improvements in Tom's Run are at least in part due to the natural depletion of exposed pyrite.

Several factors predisposed the Tom's Run restoration project to success, whereas other similar projects have failed. First, restoration activities were conducted at the scale of the entire watershed. Too often, stream restoration projects apply reach-scale solutions to catchmentscale problems (Bernhardt and Palmer, 2011). Second, restoration activities targeted the ultimate cause of pollution: abandoned mines and abandoned gas and oil wells. Restoration projects sometimes attempt to implement solutions that do not address the root cause of the loss of ecological functions, with an example being the habit of employing structural enhancements to increase habitat heterogeneity in streams that are actually suffering from chemical degradation (Walsh et al., 2005). Finally, it is important to acknowledge that Dinsmore's data show that Tom's Run was only moderately degraded by AMD, with a mainstem $\mathrm{pH}$ mean of 5.26 and mean iron concentration of $1.3 \mathrm{mg} \cdot \mathrm{L}^{-1}$ in 1967. Indeed, the large effort directed at remediation in the 1970s was motivated in part by Dinsmore's assessment that Tom's Run was a recoverable ecosystem. More severely polluted streams will be more difficult to restore, and it is not yet known whether streams severely degraded by AMD can recover over a several decadal time scale with current remediation methods. This result does highlight, however, the wisdom of prioritizing AMD restoration efforts such that moderately degraded systems are addressed first, as these are the streams that are the most promising candidates for successful remediation.

The number of stream restoration projects undertaken within both Europe and the U.S.A. has grown exponentially in the last decade, and large sums of money are expended annually on stream and river restoration efforts (Bernhardt et al., 2005). Given the large effort expended on restoration, there are relatively few studies in the peer reviewed literature evaluating the success of restoration efforts (Brooks and Lake, 2007; Louhi et al., 2011). Furthermore, published studies of restoration often encompass only limited spatial and temporal scales (Palmer, 2009). In order to carefully evaluate the extent to which restoration projects are successful in restoring water quality, data need to be collected both before and after restoration, and more monitoring needs to occur at larger scales (Muotka et al., 2002).

In sum, our data suggest that with appropriate remediation efforts and time, streams affected by AMD can successfully recover. As stream restoration efforts continue to expand, it is important that quantitative monitoring of a variety of response variables, both pre- and postrestoration, is implemented. Further, sampling programs that are conducted over broad spatial and temporal scales will yield more meaningful information than narrowly focused studies. 
Effective restoration ultimately hinges on the application of sound ecological principles, and effective monitoring programs need to play a key role in this important work.

\section{ACKNOWLEDGEMENTS}

We would like to thank Dale Luthringer, Environmental Educator for Cook Forest State Park, for his participation and guidance in this project. We would also like to thank the following individuals for their involvement in sampling and/or revisions of earlier drafts of this manuscript: Heather Mitchell, Alicia Wells, Chris Roskosh, Josh Martz, Andrea Roessing, Randi Tyler, Matt Gordon, Joe Fiedor, Lucas Brown, Daniel Williams, and Elaine Williams.

\section{REFERENCES}

Akcil A. and Koldas S., 2006. Acid mine drainage (AMD): causes, treatment and case studies. J. Clean. Prod., 14, 1139-1145.

Alvial I.E., Tapia D.H., Castro M.J., Duran B.C. and Verdugo C.A., 2012. Analysis of benthic macroinvertebrates and biotic indices to evaluate water quality in rivers impacted by mining activities in northern Chile. Knowl. Manag. Aquat. Ecosyst., 407, 01.

APHA, 1998. Standard Methods for the Examination of Water and Wastewater, 20th edition. American Public Health Association, Washington, D.C.

Bain M.B., Harig A.L., Louchs D.P., Goforth R.R. and Mills K.E., 2000. Aquatic ecosystem protection and restoration: advances in methods for assessment and evaluation. Environ. Sci. Policy, 3, S89-S98.

Bernhardt E.S. and Palmer M.A., 2011. River restoration: the fuzzy logic of repairing reaches to reverse catchment scale degradation. Ecol. Appl., 21, 1926-1931.

Bernhardt E.S., Palmer M.A., Allan J.D., Alexander G., Barnas K., Brooks S., Carr J., Clayton S., Dahm C., Follstad-Shah J., Galat D., Gloass S., Goodwin P., Hart D., Hassett B., Jenkinson R., Katz S., Kondolf G.M., Lake S., Lave R., Meyer J. L., O’Donnell T.K., Pagano L., Powell B. and Sudduth E., 2005. Synthesizing U.S. river restoration efforts. Science, 308, 636-637.

Bott T.L., Jackson J.K., McTammany M.E., Newbold J.D., Rier S.T., Sweeney B.W. and Battle J.M., 2012. Abandoned coal mine drainage and its remediation: impacts on stream ecosystem structure and function. Ecol. Appl., 22, 2144-2163.

Brooks S.S. and Lake P.S., 2007. River restoration in Victoria, Australia: change is in the wind, and none too soon. Restor. Ecol., 15, 584-591.

Cravotta C.A. III, Brightbill R.A. and Langland M.J., 2010. Abandoned mine drainage in the Swatara Creek Basin, Southern Anthracite Coalfield, Pennsylvania, USA: 1. Stream water quality trends coinciding with the return of fish. Mine Water Environ., 29, 176-199.

Dangles O., Malmqvist B. and Laudon H., 2004. Naturally acid freshwater ecosystems are diverse and functional: evidence from boreal streams. Oikos, 104, 149-155.

DeNicola D.M. and Stapleton M.G., 2002. Impact of acid mine drainage on benthic communities in streams: the relative roles of substratum vs. aqueous effects. Environ Pollut., 119, 303-315.

Dinsmore B., 1968. The Aquatic Ecology of Tom's Run, Clarion County, Pennsylvania- Preceding Watershed Reclamation. Report to the Pennsylvania Department of Mines and Mineral Industries, Bureau of Coal Research, and the Pennsylvania Department of Health, Bureau of Sanitary Engineering.

Gerhardt A., De Bisthoven L.J. and Soares A., 2004. Macroinvertebrate response to acid mine drainage: community metrics and on-line behavioural toxicity bioassay. Environ. Pollut., 130, 263-274.

Gunn J., Sarrazin-Delay C., Wesolek B., Stasko A. and Szkokan-Emilson E., 2010. Delayed recovery of benthic macroinvertebrate communities in Junction Creek, Sudbury, Ontario, after the diversion of acid mine drainage. Hum. Ecol. Risk Assess., 16, 901-912.

Hedin R.S., 2001. Restoration of Little Hefren Run, Cook Forest State Park. Final Report. http://www2. datashed.org/sites/default/files/little_hefren_final_report.pdf.

Henry T.B., Irwin E.R., Grizzle J.M., Wildhaber M.L. and Brumbaugh W.G., 1999. Acute toxicity of an acid mine drainage mixing zone to juvenile bluegill and largemouth bass. Trans. Am. Fish. Soc., 128, 919-928. 
Herlihy A.T., Kaufmann P.R. and Mitch M.E., 1990. Regional estimates of acid mine drainage impact on streams in the Mid-Atlantic and Southeastern United States. Water, Air, Soil Pollut., 50, 91-107.

Jacobs J.A., Lehr J.H. and Testa S.M., 2014. Acid Mine Drainage, Rock Drainage, and Acid Sulfate Soils: Causes, Assessment, Prediction, Prevention, and Remediation. John Wiley \& Sons, 504 p.

Johnson D.B., 2003. Chemical and microbiological characteristics of mineral spoils and drainage waters at abandoned coal and metal mines. Water, Air, Soil Pollut. F. 3, 47-66.

Johnson D.B. and Hallberg K.B., 2005. Acid mine drainage remediation options: a review. Sci. Total Environ., 38, 3-14.

Johnson K.S., Thompson P.C., Gromen L. and Bowman J., 2014. Spatial patterns in macroinvertebrate recovery and leaf litter breakdown in an acid mine impacted stream treated with an active alkaline doser. Environ. Monit. Assess., 186, 4111-4127.

Kimmel W.G., 1983. The impact of acid mine drainage on the stream ecosystem. In: Majumdar S.K. and Miller W.W. (eds.). Pennsylvania Coal: Resources, Technology and Utilization, Pennsylvania Academy of Science, Easton, PA.

Kimmel W.G. and Argent D.G. 2010. Stream fish community responses to a gradient of specific conductance. Water, Air, Soil Pollut., 206, 49-56.

Kruse N.A., DeRose L., Korenowsky R., Bowman J.R., Lopez D., Johnson K.S. and Rankin E., 2013. The role of remediation, natural alkalinity sources and physical stream parameters in stream recovery. J. Environ. Manage., 128, 1000-1011.

Leibold M.A. and Mikkelson G.M., 2002. Coherence, species turnover, and boundary clumping: elements of meta-community structure. Oikos, 97, 237-250.

Louhi P., Mykrä H., Paavola R., Huusko A., Vehanen T., Mäki-Petäys A. and Muotka T., 2011. Twenty years of stream restoration in Finland: little response by benthic macroinvertebrate communities. Ecol. Appl. 21, 1950-1961.

Mack B., McDonald L.M. and Skousen J., 2010. Acidity decay of above-drainage underground mines in West Virginia. J. Environ. Qual. 39, 1043-1050.

Matthews W.J., 1998. Patterns in freshwater fish ecology. Chapman and Hall, New York, 756 p.

Merritt G.L. and Emrich G.H., 1970. The need for a hydrogeologic evaluation in mine drainage abatement program: a case study: Tom's Run, Clarion County, Pennsylvania. Bureau of Sanitary Engineering, Pennsylvania Department of Health. Paper presented before the Third Symposium on Coal Mine Drainage Research.

Muotka T., Paavola R., Haapala A., Novikmec M. and Laasonen P., 2002. Long-term recovery of stream habitat structure and benthic invertebrate communities from in-stream restoration. Biol. Conserv., 105, 243-253.

Nelson S.M. and Roline R.A., 1996. Recovery of a stream macroinvertebrate community from mine drainage disturbance. Hydrobiologia, 339, 73-84.

Palmer M.A., 2009. Reforming watershed restoration: science in need of application and applications in need of science. Estuar. Coast, 32, 1-17.

Plafkin J.L., Barbour M.T., Porter K.D., Gross S.K. and Hughes R.M., 1989. Rapid bioassessment protocols for use in streams and rivers: benthic macro-invertebrates and fish. EPA/444/ 4-89-001. United States Environmental Protection Agency, Washington, D.C.

Simate G.S. and Ndlovu. 2014. Acid mine drainage: challenges and opportunities. J. Environ. Chem. Eng., 2, 1785-1803.

Stafford S., Weaver T.J. and Hedin R.S., 2004. Geochemistry, hydrology, and effects from the plugging of artesian flows of acid mine drainage: Clarion River Watershed, Northwestern Pennsylvania. In National Meeting of the American Society of Mining and Reclamation. Morgantown, WV: The American Society of Mining and Reclamation.

Sundermann A., Stoll S. and Haase P., 2011. River restoration success depends on the species pool of the immediate surroundings. Ecol. Appl., 21, 1962-1971.

Sutcliffe D.W. and Hildrew A.G., 1989. Invertebrate communities in acid streams. In: Morris R., et al. (eds.), Acid toxicity and aquatic animals. Society for Experimental Biology Seminar Series, Vol. 34, Cambridge University Press, pp. 13-30.

Tomkiewicz S.M. and Dunson W.A., 1977. Aquatic insect diversity and biomass in a stream marginally polluted by acid mine drainage. Water Res., 11, 397-402. 
United States Department of the Interior. 2015. Website: http://www.osmre.gov/programs/aml.shtm Accessed Feb. 5, 2015.

Van Damme P., Hamel C., Ayala A. and Bervoits L., 2008. Macroinvertebrate community response to acid mine drainage in rivers of the High Andes (Bolivia). Environ. Pol., 156, 1061-1068.

Walsh C.J., Fletcher T.D. and Ladson A.R., 2005. Stream restoration in urban catchments through redesigning stormwater systems: looking to the catchment to save the stream. J.N. Am. Benthol. Soc., 24, 690-705.

Wohl E., Angermeier P.L., Bledsoe B., Kondolf G.M., MacDonnell L., Merritt D.M., Palmer M.A., Poff N.L. and Tarboton D., 2005. River restoration. Water Resour. Res., 41, W10301.

Wood S.C., Younger P.L. and Robins N.S., 1999. Long-term changes in the quality of polluted minewater discharges from abandoned underground coal workings in Scotland. Q. J. Eng. Geol. Hydroge., 32, 69-79.

Cite this article as: K.M. Williams and A.M. Turner, 2015. Acid mine drainage and stream recovery: Effects of restoration on water quality, macroinvertebrates, and fish. Knowl. Manag. Aquat. Ecosyst., 416, 18. 